\title{
LINGUISTICS
}

DOI: https://doi.org/10.33739/2587-5434-2021-6-1-9-21

\section{TRACES OF FINNO-UGRIC CONTACTS IN RUSSIAN FOLK SPEECH}

\author{
Imre Pacsai \\ Habilitated doctor of Philological Sciences, Professor \\ College of Nyíregyháza \\ (Nyíregyháza, Hungary) \\ e-mail: drpacsai@gmai.com \\ Zoia Adamia \\ Doctor of Philology, Professor \\ Tskhum-Abkhazian Academy of Sciences \\ (Tbilisi, Georgia) \\ email: a.zoia777@gmail.com
}

\begin{abstract}
The research of linguistic contacts is an important task, namely enlight the formation and evolution of the language, which is mentioned in the U. Weinreich's work Languages in Contact (1970). The present paper analyses some common elements of Russian folk-language and of Finno-Ugrian languages, which formed by contacts in the region of «Russian cultural zone», established by N. S. Troubetzkoy (1927). During the comparative scientific investigation, we discovered the common elements in the domain of word-creation and syntax, which reflect the old and intensive linguistic and cultural contacts between compared languages.
\end{abstract}

Keywords. linguistic and cultural contacts, comparative scientific investigation, common elements of wordcreation and the syntax, Russian folk-language, Finno-Ugrian languages, region of Russian cultural zone», coordinative compounds, reduplications.

\section{СЛЕДЫ ФИННО-УГОРСКИХ КОНТАКТОВ В РУССКОЙ НАРОДНОЙ РЕЧИ}

\author{
Имре Пачаи \\ Хабилитированный доктор филологических наук, профессор \\ Ньиредьхазская высшая школа \\ (Ньиредьхаза, Венгрия) \\ e-mail: drpacsai@gmai.com
}

Зоя Адамия

Доктор филологии, профессор

Цхум-Абхазская академия наук

(Тбилиси, Грузия)

e-mail: a.zoia777@gmail.com 
Аннотация. Исследование языковых контактов является важной задачей, прежде всего, с позиций формирования и эволюцию языка, о чем говорится в работе У. Вайнрайха «Языки в контакте» (1970). В настоящей работе анализируются некоторые общие элементы русского народного языка и финноугорских языков, сформировавшиеся в результате контактов в регионе «русской культурной зоны», установленной Н. С. Трубецким (1927). В ходе сопоставительного научного исследования были выявлены общие элементы в области словообразования и синтаксиса, которые отражают давние и интенсивные языковые и культурные контакты между сравниваемыми языками.

Ключевые слова: языковые и культурные контакты, сравнительно-научное исследование, общие элементы словообразования и синтаксиса, русский народный язык, финно-угорские языки, регион русской культурной зоны, координативные соединения, редупликации

\section{ВВЕДЕНИЕ}

В настоящей статье рассматриваются следы контактов русского народа с соседними финноугорскими народами в русской народной речи. Изучение языковых контактов является важной задачей лингвистики, о чем говорится в книге «Языковые контактыл» У. Вайнрайха (1978). Формирование русской культуры, по мнению Н. С. Трубецкого определилось культурными контактами русского народа с соседними тюркскими и финно-угорскими народами.

Изучению этих контактов посвящены работы «Верхи и низы русской культуры» (1927, переизд.: 1990) и «О туранском элементе в русской культуре» (1925; переизд.: 1990) Н. С. Трубецкого. в которых рассматриваются мотивы восточного характера русской народной культуры. В упомянутых работах сложные вопросы получили многосторонний и тщательный анализ. Он ввел в науку понятие «русской культурной зоны», освещающее многие вопросы данного комплекса.

Н. С. Трубецкой установил сущность «русской культурной зоны»: „В общем эта культура есть сама особая «зона», в которую, кроме русских, входят еще некоторые угро-финские инородцы вместе с тюрками волжского бассейна. С незаметной постепенностью эта культура на востоке и юговостоке соприкасается с культурой степной (тюрко-монгольской) и через нее связывается с другими культурами Азии" (Трубецкой 1991, 94).

В статьях Н. С. Трубецкого рассматриваются только культурные контакты. С точки зрения лингокультурологии, представленной в работе В. В. Воробьёва (1997) культура и язык тесно связаны друг с другом, что отражено в теории В. ф. Гумбольдта и его последователей.

Взаимосвязь языка и культуры подтверждается и при определении понятия «национальная ментальность» в книге В. В. Колесова (1999): «Ментальность есть средство национального самосознания и способ создания традиционной картины мира, коренящиеся в категориях и формах родного языка» (Колесов 1999, 148)

По нашему мнению, изучение русской народной речи является важной задачей, так как следы восточных контактов, отражающихся в духовной и материальной культуре русского народа, упомянутые Н. С. Трубецким, должны отражаться и в народной речи.

Выбор сферы нашего исследования объясняется тем, что восточные элементы русского языка обнаружились, в первую очередь, в русском фольклоре и в произведениях русских народных писателей, в которых звучит русская народная речь.

О расхождении между культурными нормами «верхов и «низов» русского общества, упомянутом Н. С. Трубецким (1927), говорится и в статье «Наптное» ? В. Даля, дополняющей сборник русских пословиц. Он указал и на расхождение между свойствами языка этих основных классов русского общества в середине 19-го века. 
Фольклор и работы русских народных писателей послужили для нас богатым источником, в которых мы нашли много примеров данного вида словотворчества и другие языковые элементы, типичные и для финно-угорских языков.

Сфера нашего исследования нашла подтверждение в книге «Практическая стилистика» Д. Э. Розенталя (1974), так как восточные мотивы соответствуют категориям русской разговорной речи, представленным в его работе.

Исследование русской народной речи, по мнению Ф. П. Филина (1975) является нелегкой задачей для лингвистов. Выводы Ф. П. Филина подтверждаются слова П. И. Мельниковым, в его романе «На горах», затрагивающем проблему недостатков письменных памятников о жизни русского народа:

«У русского простонародья нет ни летописных записей, ни повести временных лет, ни иных писанных памятей про то, как люди допрежь нас живали... Но есть живучие преданья...» (МЕЛ 138)

Наше исследование было мотивировано выводом немецкого лингвиста, В. Феенкера о направлении нашего исследования относительно изучения парных слов в русском и финно-угорских языках. В. Феенкер (1967) заложил основу исследования финно-угорского субстрата в русском языке. Его теория находит подтверждение в работе украинского лингвиста О. Б. Ткаченко (1979), который установил финно-угорское происхождение словосложения «жил-был», типичного элемента присказки русских народных сказок. Сотрудничество с профессором О. Б. Ткаченко тоже содействовало изучению финно-угорских контактов. Результатам нашего общего исследования была посвящена серия «Следы языковых и культурных контактов в русском фольклоре и фразеологии» (2002), в которой были опубликованы достижения нашей работы.

В настоящей статье рассматриваются вопросы, связанные с словотворчеством и синтаксисом русской народной речи и финно-угорских языков.

\section{О парных словах в русском и финно-угорских языках}

При изучении языков русской культурной зоны, установленной Н. С. Трубецким (1927), мы обнаружили общие структуры в русском и финно-угорских языках, которые свойственны восточным языкам и малоизвестны в европейских языках.

Для венгерского исследователя парные слова были известны, так как они являются типичными структурами венгерского языка. Они издавна рассматривались самыми выдающимися венгерскими и зарубежными учеными: Фокош Ф. Д., Бэке Э, Келемен Й, Раиш Д., Э. Леви, К. Э. Майтинская и т.д.

При сопоставлении структуры и функции парных слов в русском и финно-угорских языках выделились общие характерные черты данного вида словотворчества. Мы стремились найти освещение данной проблемы в работах русских лингвистов, но ни в работах по разговорной речи, ни по словосложению, вышедших в свет в 20-м веке, не нашли анализ этих своеобразных структур.

Это было непонятно для нас, так как в книге «Из записок по русской грамматике» Т. 3 (1899) А. А. Потебни посвящено около 50 страниц трактовке парных слов в русском языке. Он установил их древний характер, и указал на то, что они использованы в первую очередь в просторечии и в фольклоре. Выводы А. А. Потебни свидетельствуют о том, что парные слова обладают специфическим стилистическим характером и связаны с русской народной культурой и с народной речью.

Мы нашли интересный материал в словаре по фразеологии «Русские фразеологизмы»» В. П. Фелыциной и В. М. Мокиенко (1990). В данной работе после долгого молчания были изучены парные слова в русском языке жил-был, любо-дорого, подобру-поздорову, тары-бары, хлеб-соль и использован термин «русская народная речь», к которой принадлежат парные слова: 
«nодобру-поздорову: Выражение построено по типичной для народной русской речи формуле, объединяющей сходные по смыслу слова нежданно-негаданно, цел и невредим, ни конца ни краю, судить да рядить, не думать не гадать». (Фелыцина, Мокиенко 1990, 105).

При изучении сборников по русскому фольклору обнаружились структуры, использованные в разных жанрах русского народного творчества:

былины: поил-кормил (РНC 17); злата-серебра (РНС 27); пьют-едят (РНC 39); чашкиложки (ИП 59); рать-силу (ИП 142);

народные песни: друзья-товарищи (ИП 268), ума-разума (ИП 263), печаль-тоска (ИП 271), роду-племени (ИП 191); отца-матери (КИР 47); спал-почивал (КИР74), грусть-тоска (КИР 85); живот-сердце (КИР 254), житье-бытье (КИР 91),

народные сказки: жил-был (ВСк); видимо-невидимо (АФ 145); угостила-употчевала (АФ 148), путь-дорогу (АФ 161); подобру-поздорову (1АФ 50)); друга-товарища, любо-дорого (АФ 163 ) звать-величать (АФ 178)

В произведениях народных писателей тоже используются парные слова:

Мельников: путь-дорогу (МЕЛ 78); поры-времени (МЕЛ 78); счастье-талан (МЕЛ 348); друзьяприятели (МЕЛ 385); нежданно-негаданно (МЕЛ 451); Бажов: жив-здоров (БАЖ 83) клястьсябожиться (БАЖ 143); иестно-благородно (БАЖ 105); Шолохов: подобру-поздорову (ШОЛД 38); таких-сяких (ШОЛД 78); ииб-прошиб (ШОЛД 193); Шукшин: жить-пожсивать (ШБ 62); хлебсоль (ШР 74); живы-здоровы (ШБ 446); прищей-пристебай (ШБ 393); Белов: судили-рядили (БЕЛ 34), любо-дорого (БЕЛ 23); пень-колоду (БЕЛ 12); Залыгин: пахать-сеять (ЗАЛИ 94); поитькормить (ЗАЛИ 94); одевал-обувал (ЗАЛИ 27); братья-сестры (ЗК 274); кормилец-поилец (ЗК 377); рукам-ногам (ЗК 222); роду-племени (ЗК 54); Распутин: худо-бедно (РАСП 13); отцу-матери (РАСП 30); шиворот-навыворот (РАСП 40); житье-бытье -(РАСП 41); шито-крыто (РАСП 86);

При нашем компаративном исследовании удалось найти семантические эквиваленты русских и финно-угорских сочинительных сложений, (парных слов).

Заслуживает внимания, что О. Б. Ткаченко (1979) считал важной задачей сопоставление структуры жил-был, то есть изучение данного вида словотворчества. Типичному зачину русских народных сказок жил-был и образованной от него структуре житье-бытье соответствуют эквиваленты финно-угорских языков, представленные в работе О. Б. Ткаченко: коми овны-в̈̈вны (КРС 202), удмурт. улыны-вылыны (УдРС. 449) «То же», мордовск. эрямс-аштемс (ЭРС 778) «То же».

В русской народной традиции значение здоровья, благополучия выражается интенсивным использованием конструкции жни-здоров, эквиваленты которой были обнаружены в финно-горских языках.

В работе А. А. Потебни говорится о давнем характере парных слов, обозначающих степени родства: отец-мать, братсестрома, мужеженами. В сопоставительной работе Э. Леви, Э. Беке, Д. Ф. Фокоша и К. Е. Майтинской тоже упоминается о древнем характере этих парных слов, обозначающих степень родства в финно-угорских языках:

удм.: анай-атай; муми-айы (РудС 303) «родители, отец и мать»; коми: ай-мам (КоРС 17) «то же»; морд: тетяm-ават (ЭРС659) «родители, отец и мать»; патят-сазорт (ЭРС 461) «сестры, старшая сестра и младшая сестра».: мари.: ача-ава (МаРС 25) «родители, отец и мать»; ача-коча (МаРС 25) «предки, отец и дед»; акак-шужарак (МаРС 15) «сестры, старшая и младшая сестра»; венг.: apa-anya «родители, отец и мать»;

Понятия «здоровье, благополучие, сохранность» часто обозначается парными словами синонимического типа в восточно-евразийских языках. Типичной формулой речевого этикета русской народной речи является структура жив-здоров, отражающая восточное влияние. Эта формула наблюдается в сборнике В. И. Даля «Жив-здоров, ни горельный ни больной» [Д I/ 309], 
также широко используется русскими народными писателями, изображающими быт русского народа:

В романе М. Шолохова «Тихий Дон» наблюдается высокая частотность использования структуры ж⿻ив-здоров, что свидетельствует о её широком распространении в русской народной речи.

«Наталья с внуками как? Живы-здоровы?» (Ш. II.65); «Здравствуй, сват! Живой-здоровый?» (Ш. II.96); «Супруга ваша живая-здоровая?» (Ш. III.60); «Натальюшка жсива-здорова?» (Ш. III.140); «Детушки живы-здоровы» (Ш. IV.422); «Живой-здоровый он?» (Ш. IV.249); «Бог даст, жживыхздоровых увидим.» (Ш. IV.33).

Русский фразеологический оборот подобру-пздорову (РФ 546) раньше явился синонимом структур жив-здоров, в целости-сохранности, о чем упоминается в работе «Русская фразеология» (2005). В ХІХ-м веке выражение доехать / добраться подобру-поздорову имело значение «благополучно», жить подобру-поздорову имело значение «хорошо». Позже выражение теряло исконное значение. По семантике компонентов добр и зрав - это сложение обозначало понятие «целым, живым», которое относится к изучаемому семантическому полю.

Сложения мордовского языка шумбра-паро (ГМЯ 132) «крепкий и здоровый» к < шумбра (ЭРС 767) «1) крепкий, здоровый; 2) сильный, крепкий» + паро (ЭРС 768) '1) хороший; 2) «добротный»; [шумбракстомс (ЭРС 768) «поздороваться»] шумбрасто-парсте (ЭРС 768) «В целости и сохранности»; сложение шумбрат-napm (ЭРС 768) «здоровье (пожелание)» отражают сходные семантические признаки с русским оборотом подобру-поздорову по семантике компонентов..».

Структура шумбра-таза (ГМЯ 132) «крепкий и здоровый» < шумбра «крепкий, сильный» + таза (ЭРС 458) «крепкий (о человеке)» является синонимом структуры шумбра-паро. О многогранном характере контактов свидетельствует и данная структура, использующая слово таза, заимствованное из тюркских языков.

О широком использовании лексемы шумбра (ЭРС 767) в мордовском речевом этикете и языковой модели говорят и обороты шумбрат (ЭРС 768) «Здравствуй!» шумбрачи (ЭРС 768) «1) здоровье; 2) пожелание здоровья и счастья».

Венгерская формула речевого этикета народной речи Eröt-egészséget! стал формулой венгерского военного языка и используется на военных парадах. Данная формула имеет социокультурный характер, так как используется мужчинами при прощании или за столом при чоканье. О диалектном характере этой формулы свидетельствует тот факт, что формула Erötegészséget! сохранилась в первую очередь в Трансильвании, в регионе Восточных-Карпат у секлеров.

Эта формула состоит из компонентов erö 'сила' и egészség 'здоровье'. По семантике структуры и ее компонентов мы можем установить сходство между мордовскими структурами шумбра-паро и шумбра-таза, в которых используются компоненты со значением «сила» и «здоровье».

Известная формула поздравления Зравствуй! / Зравствуйте! свидетельствует о том, что понятия «здоровье, благополучие, сохранность» имеют важное место в русском национальном менталитете.

Формула «Здорово!» по токованию словаря С. И. Ожегова (1987) относится к лексике просторечия. Эта формула часто используется как в языке фольклора:

«-Здорово, старик! Средь бела дня не украдешь», (НРС 263); «-3дорово, кума! — Здравствуй, говорит лиса.» (НРС 28); «- Здорово, хозяин! - Здорово служба!» (НРС 303); так и в народной речи, звучащей в работах народных писателей:

«- Здорово, Ермило Матвеич!.» (МЕЛ 347) «- Здорово, бабушка! Поклон от старика.» (ШолТД IV/ 33); «Генка пошел к дяде Грише...- Здорово, дядь Гриша!» (ШУКБ 202); «Здорово, Михеич!» (ШУК 84); «- Здорово, Брусенков! — протянул ему руку Ефрем.» (ЗАЛС 29); «Здорово, Дарьюшка! — гудел он.» (Расп 27). 
При прощании друг с другом крестьянские герои произведений народных писателей пользуются формулой «Будь здоров!», которая также содействует установлению couleur local-a деревни:

«Ну, бывай здоров! — Федя поднялся уходить.» (ШУКШ 138); «- Вот так...Будьте здоровы пока. - Спирька вышел.» (ШУКШБ 74); «Ну, тогда прощай, Власихин.! Бывай здоров!» (ЗАЛС 29); «С богом, Ефрем. Будь здоров!» (ЗС 102); «-Будь здоровая, Дора! - Наклонился. Поцеловал в лоб и ушел.» (ЗЛС 437)

Об ареальном характере русских речевых формул «Здорово!» и «Будь здоров!» свидетельствуют речевые формулы финно-угорских языков. Формулы речевого этикета марийского языка «эсен улыда!» (МарРС 454) «здравствуйте! (букв.: будьте здоровы!)» и «таза лийза!» (МарРС 321) «будьте здоровы!» тоже отражают ментальность изучаемого ареала.

Мордовская формула приветствия Шумбрат! «Здравствуй(те)!» (букв.: здоровье!) тоже относится к данному семантическому полю.

Своеобразная формула русского народного языка «Доброго здоровья», имеет соотношение с фразеологической единицей «подобру-поздорову». Эта форма приветствия народа использована в следующем примере: «一 Доброго здоровья, — приветствовал старик в шляпе» (ШУКШ 33),

Кроме понятий, связанных со здоровьем и благополучием парные слова numb-ecmb, кормить-поить, угостить-употчевать, хлеб-соль, мед-вино, чашки-ложки и формулы народного речевого этикета Хлеб да соль!, Чай с сахаром! /Чай да сахар!, свидетельствуют о роли понятий «кормление, угощение». При изучении лексики финно-угорских языков обнаружились параллельные структуры представленных русских сложений.

В мордовском языке мы обнаружили много структур, связанных с изученным семантическим полем. ярсамс-симеммс (ЭРС 804) «1) есть и пить; 2) пировать»; симемс-ярамс (ЭРС 587) «пировать (букв.: пить и есть)»; трямс-андомс (ЭРС 679) «выкормить и воспитать: Одирвась тризе-ванызе, сон кастызе-кепетызе (Молодуха выкормила его, вынянчила, взрастила и воспитала)»; андозьсимезь (ЭРС 49) «накормленный и напоенный»; андомс-симдемс (ЭРС 49) 'Угостить (букв.:накормить и напоить)'; симдемс-андомс (ЭРС 586) «напоить и накормить < симдемс (ЭРС 586) напоить» + андомс (ЭРС 49) «накормить»; трямс-растамс (ЭРС 679) «воспитать, вырастить»; пидемс-панемс (ЭРС 476) «готовить, стряпать» < пидемс (ЭРС 476) «1) варить, сарить; 2) готовить + панемс (ЭРС 455) «печь испечь» панемс прякат «печь пироги».

Русской структуре кормить-поить соответствуют парные слова удмуртского языка сюдыны-люктаны (УдРС 406) «кормить, накормить (кормить и поить)» < сюдыны «кормить»+ люктаны (УдРС279) «поить, напоить»; коми структуры вердныл-удны (КоРС 38) «кормить, растить»; вердны-юктаны (КоРС 38) «кормить и поить»; удны-вердны (КоРС 509) «угостить, напоитьнакормить»; коми: yдісь-вердісь (509) «кормилец-поилец»; марийская структура пукшаш-йукташ (МаРС 269) «кормить и поить» < пукшаш (МаРС 269) «питать, кормить кого» + йукташ (МРС 90) «поить, напоить кого», использованная в обороте пукшен-йуктен кушташ (МаРС 269) «скормить и вспоить».

Понятие «угощение» передается русским сочинительным сложением угостить-употчевать, используемым в сказке «Поди туда - не знаю куда, принеси то - не знаю что» (НРС 159-175) из сборника А. Н. Афанасьева:

«ты зови купцов, угости-употчевай и променяй меня на три диковинки, чтобы купцы с собой везут.» (НРС 172).

Удмуртское сложение сюдыны-утялтыны (УдРС 406) «угостить, употчевать» и марийское сий-курмат (МаРС 305) «угощение, чествование» < сий (МаРС 305) «угошение» + курмат чествование' связаны с упомянутыми традициями региона.

Об ареальном характере этих парных слов свидетельствует тот факт, что они вместе с русским сложением угостить-употчевать обладают общей структурой и обозначают общее понятие. 
Вариант этой формулы наблюдается в романе «На Иртыще» С. Залыгина. Эта формула, используется вместе с другой формулой акцентируя его стилистический характер: «- Здорово, Степша! Чай с сахаром!- Здорово. Садись.» (ЗНИ 521)

Венгеерские структуры eszik-iszik «питается (ест и пьет)»; etet-itat «кормит-поит (дает есть и рить); étel-ital «пища (еда и напитки)»; süt-föz» 1) варить, сварить; 2) готовить < süt «жарит»+ föz «варит». Заслуживает внимания семантическое тождество с мордовской пидемс-панемс «готовить, стряпать», что подтверждается тождественным значением компонентов. Венгерская структура sütfö $\boldsymbol{z}$ используется в венгерской фразеологической единице sülve-föve együtt vannak'они неразлучны / в купе и любе с кем (букв.: они, вместе варя и испекая).

Сложение чашки-ложки (22, с. 59) «столовая / кухонная посуда» тоже связано с данным семантическим полем. Эквиваленты в языках изучаемого ареала отражают общую функцию: коми: macьmi-nань (КоРС 23, с. 665) «столовая посуда» < macьmi (КоРС 23, с. 665) «чашка» + «пань» (КоРС 23, с. 426) «ложка»; удм: myсты-пуньь (УдРС16, с. 432_ «чашки-ложки, кухонная посуда» < mусты «чашка» + пуньь «ложка»; морд: пенчть-вакант [24, с. 132] «посуда» < пенч «ложка»+ ва.

Соприкосновение русского народа с народами Поволжья отражается и в образном, метафоричном выражении явлений душевного мира. В русских народных песнях мы нашли следующие примеры: «У молодиа, у парничка живот-сердце бъетиа» (Кир. 146/306); «Сударочки найдеть - жсивот-сердце мреть» (Кир. 254/555); «живот-сердце нарывана» (Писемский, НСП 314). При помощи парного слова живот-сердце образно передается сущность понятия «душа», что свидетельствует как о специфическом, образном характере языка фольклора так и ареальном характере данной структуры.

В удмуртском сложении кӧтъя-сюлэмъя (УРС 216) «по душе, по сердцу» обнаруживается соответствие компонентов русской и финно-угорской структуры, которая состоит из слов кӧт (УдРС 216) «живот» и сюлэм (УРС 407) «сердце».

Марийское сложение шум-моки (МаРС 434), состоящее из компонентов шум (434) «сердце» и мокш (192) «печень» кроме значения «внутренности, ливер», используется и в переносном значении «душевный мир человека».

Мордовские парные слова седейсть-максот (Э) / седихть-максот (М) (ГМЯ 132) «внутренности, ливер» < седей / седи «сердце» + максо / макса «печень», в которых обнаруживаются эквиваленты марийских слов, также примыкают к семантической группе ареала.

В русской народной речи тоже используется структура знать-видать, которая используется в русской народной сказке «Не любо - не слушай» (НРС 279-280) из сборника А. Н. Афанасьева:

«никто меня не знал, не видал, только знала-видала меня рогатая скотина» (НРС 280).

Эквивалентом русской структуры знать-бидать является удмуртское сложение тодылыныадзылыны (УдРС 418) «знать, Узнать, познать, испытать, пережить, изведать» < тодылыны «знать, узнать» < тодыны (УдРС 418) «знать, узнать» + aдзылыны (УдРС 418) «увидеть, испытать» < адзыны (УдРС 418) «1) видеть, 2) замечать, примечать, 3) испытывать». Значение уточняется оборотом тодэм-адзем адями (УдРС 418) «бывалый человек; стрелянный воробей».

Парные слова пахать-сеять «возделывать землю» и пахарь-сеятель «земледелец, хлебопашец» используются в романах «Соленая падь», «На Иртыше» и «Комиссия» С. Залыгина, в которых звучит речь коренных жителей «чалдонов» Западной Сибири: «живой останется, вырастет, naxamb-ceяmb будет» (ЗС 97), „Ну, зачнем naxamb-ceяmb, тогда уже, конечно, сами по себе станем (ЗНИ 560), „и пошел по ниве пахарь-сеятель с конем своим” (ЗК 211).

Данные сложения связаны с понятием «заниматься хлебопашеством, обрабатывать землю», которые имеют эквиваленты в финно-угорских языках:

коми-перм.: гёрны-кӧдзны (КоПРС 107) «пахать + сеять» и гёрись-кӧдзись (КоПРС 107) «пашущий + сеющий > земледелец, крестьянин», удмуртское герон-кизён (УдРС 106) «вспашка + посев», обработка земли; марийское курал-їдаш (МаРС 144) «пахать + сеять, обрабатывать землю»; 
мордовское видемс-сокамс (ЭРС 132) «сеять + пахать» / сокамс-видемс «пахать + сеять > заниматься хлебопашеством», сокиця-видиця «пахарь», земледелец, хлебопашец' также являются параллельными сложениями.

О древнем характере венгерских структур szánt-vet «заниматься хлебопашеством, обрабатывать землю» < szánt «пахать» + vet «сеять»; szántó-vető «земледелец, хлебопашец» < szántó «пашущий»+ vető «сеющий» свидетельствует работа Calepinus-a (XVI в.), в которой упоминается об этих сложениях.

Сложение друг-товарищ (ИП 268) используется в исторической песне 17-го века: «Все то наши друзья-товарищи» (ИП 268), вариантом которого является друг-приятель (МЕЛ I/191), которую мЫ нашли в литературном произведении: «...там все кругом знакомые, дружки-приятели» (Бел 90).

Параллельными сложениями являются мордовское оят-ялгат (ЭРС 449) «друзья»< оя «друг, приятель» + ялга (ЭРС 802) «товарищ, друг»; удм.: эшъёс-юлтошъёс (УдРС 526) «друзья-товарищи» $<$ эш (УдРС 526) «товарищ» + юлтош (УдРС 530) «друг, приятель, товарищ, спутник».

Наше сопоставительное исследование затрагивает еще один языковой уровень синтаксический.

При трактовке специфических признаков русской разговорной речи Д. Э. Розенталь (1974) обнаружил, что большим своеобразием отличается разговорный синтаксис. Кроме категорий, свойственных для разговорной формы литературного языка используются и структуры, которые типичны для народной речи. В фольклоре и в литературных произведениях народных писателей были найдены многие подтипы синтаксических категорий, трактуемых в работе Д. Э. Розенталя.

Типичными структурами русской народной речи являются неполные тождественные повторы день деньской, кищмя кищеть, один-единственный, полным-полно, ревмя реветь,, которые в лингвистике называются термином «figura etymologica».Эти структуры являются типичными элементами русского фольклора и языка, использованного русскими народными писателями.

Они широко используются в фольклоре: «Вали валом, после разберем» (Д II/ 66) «Течьмя течет. Ливмя льет. Лётом летит» (Д ІІ./21) «и давай рубить яблоню крест-накрест» (НРС 90); «День деньской - как за язык повешенный» (Д I/380) «Много-множество е в мире согрешения» (РНС 174); «и стал работник перед царским лицом молодец-молодцом» (НРС 229); «сползались со всех сторон на берег раки большие и малые - тьма-тьмущая!» (НРС 140); «Доселева русского духа видом не видать, слыхом не слыхать» (НРС 78);

В литературных произведениях, использующих типичные категории русского народного языка, часто встречаются неполные тождественные повторы. Типичными структурами являются повторы, в которых используется словосочетание, состоящее из глагола и деепричастия, образованного от данного глагола:

«- Дрожмя дрожат-с, до конца сробели.» (МЕЛ 116); «Лётом вылетел головой вон из залы». (МЕЛ 303); «Кто сидит, кто лежмя лежит, вовсе камнями стали.» (БАЖ 6); «а снег-от бегом побежал.» (БАЖ 127); «И там этих беленьких кишмя кишело.» (ШУКШр 62); «— Да пропади она пропадом, распроклятая эта Комиссия!» (ЗАЛК 105); «—Телята вон в телятнике ревмя ревят.» (БЕЛ 41); «— Невестка ругмя ругает» (БЕЛ 373); «- Слышу, как оно ходит в боченках ходуном.» (ЗК 442); «И кричком кричал Гришка» (ЗС 297); «Тайга на десятки вёрст гудом гудела от машины» (РАСП .40); «Колчаковцы, захватив остров, слыхом не слыхали про Пашу.» (РАСП 129);

Им соответствую нижеприведённые коми структуры.

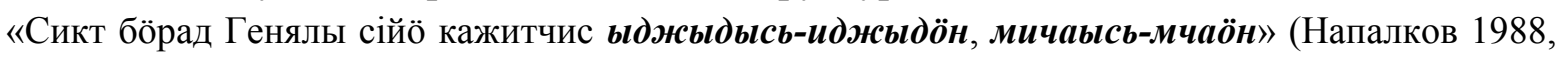
49) «После села он показался Гене огромным (букв.: из больших самый большой)»; «Коми муысь белӧй-ясӧс вӧтлӧм бӧрын коркӧ-некоркӧ мужичӧйяс бӧр воаліни сиктӧ» (Напалков 1988, 101) «После изгнания белых с коми земли постепенно (букв.: когда никогда) мужчины стали возвращаться 
в село»; «- Водзысь-водз ветлан, Наденька.»; (Напалков1988, 129) «В такую рань (букв.: из раннего времени самое раннее ходит Наденька»;

В сопоставительном исследовании мы обнаружили сходные по своим типологическим признакам структуры в мордовском языке. Данные структуры тщательно изучены в работе «Грамматика мордовских языков». (1980). В составе мордовских структур данного вида наблюдаются повторы, соответствующие русским повторам: «Чись, прок якстере шар, кеверезь кеверсь валгомав.» (ГМЯ 359) «Солнце словно красный шар покатилось (букв.: катясь катилось»»; «Обед. Чись пидезь пиди.»(ГМЯ 359) «Обед. Солнце сильно печет. (букв.: припекая печет)»; «Менельста солазь соласть ашназа паргу туцятне.» (ГМЯ 359) «На небе быстро таяли пышные белые облака. (букв.: тая таяли)»; «Пингсь ласкозь ласксь» (ГМЯ 359) «Время бежало быстро. (букв.: убегая бежало)».

Структура марийского языка, восходящая к глаголу шинчаш (МРС 411) «сидеть» тоже обладает сходными признаками: шинчын шинчаш (МРС 411) «сиднем сидеть».

Венгерские повторы типа figura etymlogica várva vár «с нетерпением ждет (букв.: ожидая ждет)», tudván tudja «хорошо знает (букв.: зная знает)», kérve kér «просить-молить (букв.: упрашивая просит)» рассматриваются во многих лингвистических работах (Фокош 1936, Келемен 1938, Паиш 1951, Матаи 1995).

В русском языке обнаруживаются структуры данного вида повторов, состоящие из именных компонентов:

«А мир смущает да смущает, вольной волюшки хочется...» (МЕЛ 356); «Генерал едет из Питера, строгий-настрогий.» (МЕЛ 221); «в избе у него голым-голохонько» (Баж 57); «- Я вижу, шутки шутками, а пора уж хвост на сторону» (ШолДР 45); «Мы знаем одно местечко, где не косят, а ягоды красным-красно» (Шр 111); «- Лето пропас чин чином.» (БЕЛ 455); «Матвейка глядел мрачнее мрачного, но пошевелился нисколько» (ЗК 254); «Поди-ка, здоров-здоровошенек...!» (ЗК 359); «Спокойней спокойного помер, дай-то бог и мне.» (РАСП 142).

Повторы, состоящие из номинальных (именных) элементов, тоже используются в финноугорских языках:

Мордовские структуры: келидонга келиста келеномс (ГМЯ 376) «раскинуться очень широко (букв.: шире широкого)»; „шуванядонга шуваняста китирдемс (ГМЯ 376) «тонко-тонко прясть (букв.: тоньше тонкого)», серидонга сяда сериста касомс (ГМЯ 376) «выше всех вырасти (букв.:выше высокого)».

Удмуртские: ас черсонзе черсе «свою пряжку прядет»; улонэз улиз «жизнь прожил»; лобанзэ лоба, ном кытчы пуксёз? «летать летает, а где сядет?»; серем серемек «шутки шутит»; кӧтыз кӧт, вылыз-выл, кылыз ыл «живот животом, тело телом, язык языком (ничпго оригинального)»; питемлесь пи «на бессыновье сын»; няньтешлесь нянь «на бесхлебье хлеб»; нимыз нимьши «званье зовутка».

Венгерские сруктуры: szépséges szép «очень красивый (букв.: красным красивый)»< szép «красивый», réges régi «старинный, старейший (букв.: старинно старый)» < régi «старый, старинный, давний»; vénséges vén «очень старый (був.: старинно старый) < vén ' старый».

В данных примерах наблюдаем повторы данного вида в составе обстоятельств:

«Остался Илюха один-одинёиенек.» (Баж 61); «Целовальчиха рада-радахоька» (Баж 82); «Железко сухим-сухохонек да еще посмеивается» (Баж 225); «Небо - синим-синё, и уж дергал ветер.» (Шр 106); «Автобус - полным-полна коробушка - наконец подкатил» (Бел 212); «Однажды раным-рано Иван Африканович зашел в огород» (Бел 85); «Войны давным-давно прошедших времен» (ЗК 37); «Он рад-радёшенек» (ЗК 342); «И так у всех, кто хоть мало-мальски присматривал за ней.» (Расп 120);

В финно-угорских языках тоже используются параллельные структуры: 
марийский: тевлет-теве (МРС 328) «всегда»; йырым-йыр «кругом, по всей окружности»; (МРС 96); кид-кида( МРC 114) «нарасхват, дружно» < кид «рука»; веран-верышке (МРС 38) «по местам»< вер «место»; мордовск. келейде келейсте «очень широко (букв.: шире широкого)»;

мордовские: келидонга келиста келеномс (ГМЯ 376) «раскинуться очень широко (букв.: шире широкого)»; шуванядонга шуваняста китирдемс (ГМЯ 376) «тонко-тонко прясть (букв.: тоньше тонкого)», серидонга сяда сериста касомс (ГМЯ 376) «выше всех вырасти (букв.:выше высокого)».

удмуртский: одигысь-одиг «один-единственный», чукна-цук «рано утром» (УРС 478) < чук «рано, утром»;

венгерск.: egyes egyedül «совсем одн, один-одинешенек» < еgу «один»; körös körül «кругом, по всей окружности (букв. : кругло кругом)» < kör 'круг'; körkörös (körkörös védelem) «круговой (круговя оборона)» < kör «круг»; réges régen «очень давно (букв.: давным давно)»< régen /rég «давно»; telis tele «до краев, полным-полно» < tele «полно»; véges végig «до самого конца (букв.: до кнечгого конца» < vég «конец, край»; éjten éjjel «в ночь-полночь в середине ночи (букв, ночной ночи)»< е́j «ночь».

jobbnál jobb «самые хорошие (букв. лучшие хорошего)» < jó «хороший», szebbnél szebb «самые красивые (букв.красивее красивого)».

\section{Нами были проанализированы и некоторые глагольные структуры.}

Типичными для синтаксиса народного русского языка являются структуры, которые в работе Д. Э. Розенталя (1974) названы термином «осложненное глагольное сказуемое». Этот вид глагольного сказуемого тщательно рассматривается в работе «Русские двойные глаголь и их соответствия в финно-угорских языках» Д. Вайса (2003). По результатам своего исследования он доказывает, что данные структуры обладают ареальными признаками, так как они используются и в финно-угорских языках.

Сочетание инфинитива с личной формой того же глагола (часто с отрицанием результата действия) для подчеркивания глагольного сказуемого:

Фольклор: «Прийти то приду» (РНС 315); «- Носить бы вам - не переносить, возить бы вам не перевозить» (НРС 273); «Я знать не знаю, ведать не ведаю» (Аф 255);

Литература: Мельников: «—Понять-то понял, а все-таки придумать не могу." (МЕЛ 223) «- Написать-то Доронин написал, а дела кончать не хочет» (МЕЛ 237); «-Cпешить не спеши, а все-таки маленько поторапливайся.» (МЕЛ 241); «- Знать-то знают, только мне уж лучше в иное время у них побывать.» (МЕЛ 335); «- Видать не видал, а слыхом немало слыхал, —отвечал Корней» (МЕЛ 237);

Бажов: «Вытащить ее вытащили и отводилась, да, видно, застудилась и к весне свечкой стаяла.» (БАЖ 227); «Танюшка хватилась шкатулки, $\boldsymbol{a}$ ее быть бывало.» (БАЖ 243); «Митюнька весь этот установ перенять перенял, $\boldsymbol{a}$ нет-нет и придумает по-своему.» (Баж 385); «На людей не кидаемся, а глядеть - глядим.» (БАЖ 385); «-Потерять не потерял, а найти не мог.» (Баж 278);

Шолохов: «—Pодить-то родила, только в пятый день в домовину убралась от горячки» (ШолДР 77); «— кусаться кусается, нечего греха таить, а слезу из него не вышибешь!» (ШолДР 43);

Шукшин: «а тут — как циркач на проволоке: пройти прошел, а коленки трясутся.» (ШБ 49); «Видать-то я вижж, братка, - серьезно и грустно сказал он. $-\boldsymbol{A}$ отстать не могу.» (ШБ 368); «сама знаешь: и сказать не скажет, а кусок в горле застрянет.» (ШБ 226);

Белов: «Ночевать-то ночуем, улыбнулся новоженя» (БЕЛ 325); «- приехать-то приехала, да пустая, деньги-то за дом потеряла дорогой.» (БЕЛ 375); «-Омманывать, говорит, не омманывай - это дело худое.» (БЕЛ 156); «— Тоже, Константиновна, блудить блудят, а ростить робят неохота.» (БЕЛ 307); 
Залыгин: «-Я правдой через силу не занимаюсь. Интересоваться интересуюсь.» (3С 47); «-И забыть забуду ее в одном лишь случае» (ЗК 117);

Распутин: «Схоронить меня, поди-ка, схоронют» (РАСП 117); « Придумать-то придумала...» (РАСП 219); «Мыться не мылись, а уж угостились.» (Расп 395);

В мордовских примерах инфинитивная форма с глаголом то же, что и инфинитив: ливтязь ливтямс (ЭРС 139) «бежать (букв.: летя лететь)»; уезь уемс (ЭРС 139) «идти плавно (букв.: плывая плыть)»; Туемс мон тулян, а содан, зярдо. (ГМЯ 273) «уехать уеду, не знаю когда»; Самс сай, ковда аф туй. (ГМЯ 273) «прийти придёт, никуда не денется»; Удомс мон свал удован (ГМЯ 273) «я попрежнему страдаю бессонницей»; Шархкодемс шархкодине, да аньцек аф содаса коста сявомс алашат (ГМЯ 273) «понять понял, да не знаю лошадей»;

удмуртские: шудон шудымтэ «игру играть»; пельугы пельын «серёжки в ухе»; юон юыны «пить напиток»; ужез ужаны «работать работу»; лэсьтыны лэсьтиз «сделать сделал»; кылыны ӧй кылыны «слышать не слышали»; лыдзыны лыдзи «читать читал»; жингыртыныто жингырйзы «звонить-то звонил»; адзымтэзэ адзыны «увидеть не увиденное; увидеть, пережить что-то необычайное»;

Венгерские: Látni láttam, dt nem tudom hol lakik «видеть-то видел его, но не знаю, где он живет»; Enni ettem de nem laktam jól «есть-то ел, но не насытился»; Hallani hallottam a dologról, de nem ismerem a lényegét «слышать-то слышал об этом, но подробно не знаю».

Эти структуры в русском, мордовском и в венгерском языках обладают общими синтаксическими признаками. Они указывают на то, что действие произошло, но результат не сохранился до момента речи.

\section{ВЫВОДЫ}

При сопоставлении некоторых русских структур с параллельными структурами финно-угорских языков обнаружились следы языковых контактов. Эти сходства исследовались в области словотворчества, синтаксиса и в формулах речевого этикета.

Многие из парных слов в русском языке. имеют семантические эквиваленты в финноугорских языках, которые связаны с использованием структуры, не типичной для славянских языков. Общие семантические признаки отражают и общие элементы языкового менталитета, упомянутого Н. С. Трубецким при трактовке культурных контактов русской культурной зоны.

Параллельные структуры типа figura etymologica тоже отражают специфический восточный характер русской народной речи, возникшей под влиянием языковых контактов. Использование этих структур в произведениях народных писателей содействует созданию couleur local -a, верному изображению русской народной речи.

\section{LIST OF REFERENCES}

Vaynrayh, U. (1979). Yazyikovyie kontaktyi. «Vischa shkola», Kiev.

VorobYov, V. V. (1997). Lingvokulturologiya. Teoriya i metodyi. Moskva.

Dal, V. I. (1984). Naputnoe / Poslovitsyi russkogo naroda. Sbornik V. Dalya v dvuh tomah, Moskva, s. 5-21.

Kolesov, V. V. (1999). Zhizn proishodit ot slova, Sankt-Peterburg.

Kornilov, O. A. (1994). 'Yazyikovyie modeli mira kak otrazhenie natsionalnyih mentalitetov / Rossiya i

Zapad, dialog kultur, Moskva.

Maytinskaya, K. E. (1974) Slozhnyie slova ili sootvetstvuyuschie im sochetaniya slov /Osnovyi finno-

ugorskogo yazyikoznaniya. Moskva, s. 392-396.

Mokienko, V. M. (1999). V glub pogovorki. Sankt-Peterburg. ID «MiM» «Paritet».

Mokienko, V. M. (2007). Zagadki russkoy frazeologii. Avilon. Sankt-Peterburg.

Potebnya, A. A. (1968). Iz zapisok po russkoy grammatike. T. III, Moskva. 
Rozental, D. E. (1974). Prakticheskaya stilistika russkogo yazyika. Moskva.

Tkachenko, O. B. (1979). Sopostavitelno-istoricheskaya frazeologiya slavyanskih i finno-ugorskih yazyikov.

Kiev.

Trubetskoy, N. S. (1991) Verhi i nizyi russkoy kulturyi, Vestnik Moskovskogo universiteta. ser. 9, \# 1, s. 8798.

Trubetskoy, N. S. (1990). O turanskom elemente v russkoy kulture (1925); Vestnik Moskovskogo universiteta. ser. 8, \# 6, s. 60-80.

Felitsyina, V. P., Mokienko, V. M. (1990). Russkie frazeologizmyi Lingvostra-novedcheskiy slovar, Moskva.

Filin, F. P. (1977) O geneticheskom i funktsionalnom statuse sovremennogo russkogo literaturnogo yazyika. Voprosyi yazyikoznaniya 4. s. 3-20.

Beke, Ödön (1936). A finnugor szóösszetételhtz. Nyevtudományi közltméyek, XLII. 346-356.

Fokos, F. D. (1962). 'Uráli és altaji összehasonlító szintaktikai tanulmányok'. Nyelvtudományi Közlemények. LXIV. 39-45.

Lewi, E. 1911, Zur finnisch ugrischen Wort- und Satzverbindung, Göttingen. .

Moravcsik, E.A. (1978). Reduplicative Constructions (Greenberg: "Universals of Houman

Language", Standford 298-334.)

Veenker, Wolfgang (1967). Die Frage drs finnno-ugrishen Substrats in der russischen Srache

Bloomington - The Hague.

\section{Источники и их временные сокращения}

Афанасьев. - Русские сказки. Из сборника А. Н. Афанасьева, Москва 1987.

Бажов - В. П. Бажов: Малахитовая шкатулка. Рассказы, Москва 1947.

Белов В. Белов: Повести и рассказы. «Художественная литература», Москва, 1984

ГМЯ - Грамматика мордовских языков, Саранск 1980.

Д- Пословищь русского народа. Сборник В. Даля в двух томах, Москва 1984.

ЗАЛИ Сергей Залыгин: На Иртыше Молодая гвардия. Москва. 1979

ЗК Сергей Залыгин: Комиссия Молодая гвардия. Москва. 1976

ЗС Сергей Залыгин: Соленая падь. Молодая гвардия. Москва. 1979

ИП - Исторические песни ХVII века, Ленинград 1966.

Кир. - Сборник народных песен П. В. Киреевского, Ленинград, Наука, 1983.

КоРС - Коми-пермско-русский словарь., Москва 1985.

КРС - Коми-русский словарь., Москва 1961.

МаРС - Марийско-русский словарь. Йошкар-Ола, 1991.

Ожегов - С. И. Ожегов: Словарь русского языка, Москва 1987.

Распутин. - В. Распутин: Прощание с Матёрой. Повести, Минск 1983.

РНС - Русские народные сказители, Москва Правда. 1989.

УдРС - Удмуртско-русский словарь, Москва 1983.

ШЛ - В. Шукшин Лобановы. «Молодая гвардия» Москва, 1975

ШолДР - М. Шолохов Донские рассказы. «Таврия». Симферополь, 1981

ШолТД - М. Шолохов Тихий Дон. Москва. «Худ. литература» 1962.

Шр - В. Шукшин Беседы при ясной луне. Рассказы. Москва, 1974.

ШР - В. Шукшин Рассказы. «Художественная литература», Москва 1984

ЭРС - Эрзянско-русский словарь. Москва, 1993. «Русский язык» 


\section{For citation:}

Pacsai, I \& Adamia, Z. (2021) TRACES OF FINNO-UGRIC CONTACTS IN RUSSIAN FOLK SPEECH // International Scientific-Pedagogical Organization of Philologists “ WEST-EAST" (ISPOP). Scientific Journal WESTEAST. Vol 6 N1 (October, 2021). pp. 9-21. https://doi.org/10.33739/2587-5434-2021-6-1-9-21

\section{Для цитирования:}

Пачаи, И., Адамия, 3. (2021) СЛЕДЫ ФИННО-УГОРСКИХ КОНТАКТОВ В РУССКОЙ НАРОДНОЙ РЕЧИ // International Scientific-Pedagogical Organization of Philologists “WEST-EAST" (ISPOP). Scientific Journal WESTEAST. Vol 6 N1 (October, 2021). C. 9-21. https://doi.org/10.33739/2587-5434-2021-6-1-9-21

\section{Information about the authors:}

Imre Pacsai - Habilitated Doctor of Philological Sciences Professor, Nyíregyháza High School, Member of the Scientific Council of the International Scientific and Pedagogical Organization of Philologists "West-East" - ISPOP (Nyíregyháza, Hungary)

e-mail: drpacsai@gmail.com

Zoia Adamia - PhD, acting directorof Institute of Russian Language and Literature at Tskum-Abkhazian Academy of Sciences. Visiting professor at Sukhumi State University, Deputy Director of the International Scientific and Pedagogical Organization of Philologists "WEST-EAST" (ISPOP), (Georgia).

e-mail: a.zoia777@gmail.com

\section{Сведения об авторах:}

Имре Пачаи - хабилитированный доктор филологических наук, профессор, Ньиредьхазская Высшая школа, член научного совета Международной научно-педагогической организации филологов «Запад-Восток» - ISPOP (Ньиредьхаза, Венгрия)

e-mail: drpacsai@gmail.com

Зоя Адамия - доктор филологии, и.о. директора Института русского языка и литературы Цхум-Абхазской академии наук, приглашенный проф. Сухумского государственного университета. Заместитель директора международной научно- педагогической организации филологов «Запад-Восток» (Грузия).

e-mail: a.zoia777@gmail.com

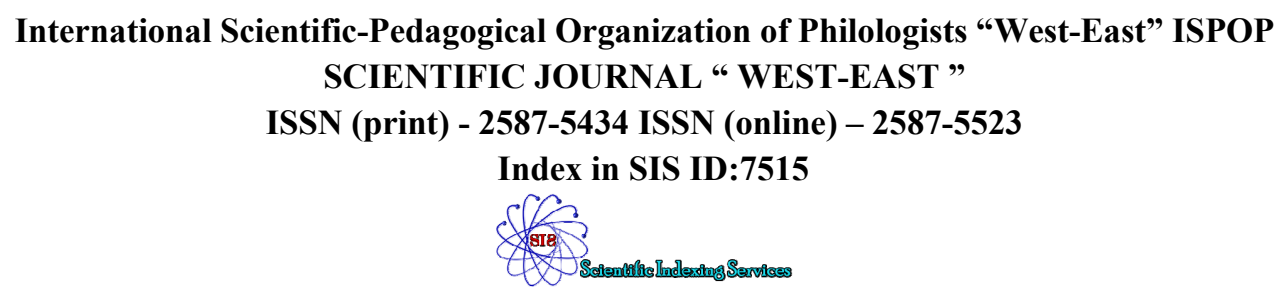

